Council libraries in India since April 1, 1959 ; for Pakistan, the corresponding figures are nearly 40,000 and 104. Measures to promote exports of British books and periodicals are making good progress, and proposals have been put to the Governments of Indonesia, Israel, Pakistan, Poland and Yugoslavia with the aim of agreeing upon schemes broadly on the lines of the former British book export schemes. Trade organizations in the periodical field have been consulted on measures to assist circulation of newspapers and periodicals in some of the more difficult markets overseas.

In broadcasting, Dr. Hill said that excellent progress has been made with the construction of the new relay transmitter at Berbera, and the Arabic Service of the B.B.C. is now transmitting for $12 \mathrm{hr}$. daily compared with $4.5 \mathrm{hr}$. in 1957. Efforts have been made to increase both the local and general appeal of the Service, and arrangements have been made to provide the local Press and broadcasting services in Fast Africa and Aden with more material on the background in the news. A conference of the Governments of the East African territories, Aden and the Somaliland Protectorate in March 1959 provided a valuable interchange of information and ideas, and the re-appraisal of the Overseas Service of the B.B.C. in English, nearing completion, has given full weight to the special importance of increasing the appeal of these Services to the rapidly growing number of listeners overseas for whom English is a second language. Studies have been made of the possibility of introducing television in Aden.

With regard to official services, a United Kingdom Information Office has been opened in Kampala and premises in Nairobi are being equipped; expenditure on television material for showing overseas is expected to be $£ 138,000$ in 1959-60 compared with $£ 121,000$ in 1958-59, and all the expansions recommended in the Central Office of Information Services have been made or are in progress. These include improvements in the Press and telegraph services, a radio-type service for local broadcasting in Arabic, Somali and Swahili ; the completion of three experimental television films for the British Council on the teaching of English; increased supply of trade and technical periodicals overseas and an expanded programme of overseas visits, especially on the Commonwealth side. A Commonwealth Exhibition, intended as the focal point of 'Commonwealth Weeks' in several major cities, was opened in Liverpool on November 19 The cost of the Overseas Information Services in $1959-60$ is now estimated at about $£ 16 \cdot 5$ million a year, while measures to promote exports of British publications will cost about a further $£ 500,000$ a year.

\title{
METALLOGENIC MAPS
}

T HE notion and the term metallogenic or metallo. genetic are due to $\mathrm{L}$. de Launay, who in 1900 proposed the terms 'metallogenic provinces' and 'metallogenic epochs'. Respectively, these two terms meant a particular geographical region or a specific geological epoch characterized by a particular assemblage of mineral deposits. The representation of such a province or provinces on the map led to the construction of metallogenic maps. Such a map differs from what is called a 'mineral map'. A mineral map only shows the distribution of one or several mineral deposits, while the aim of a metallogenic map is not only this but also to relate the distribution of such deposits to the geological formations or periods and to the tectonic features of the region. This leads to the discovery of particular areas of distribution or zones of occurrence ; changes in the character of mineral deposits in time; association of certain chemical elements among the deposits, and many other features.

During the past few decades the problem of construction of metallogenie maps of various countries or on an international basis has been discussed. At the International Geological Congress held in Mexico City in 1956 a Sub-Commission for the Metallogenic Map of the World was created. During March-April 1958 this Sub-Committee, as a part of the wider Commission of the Geological Map of the World, met in Paris (Nature, 182, 502; 1958). At this meeting a number of metallogenic maps of difforent countries were shown and discussed and the future programme outlined.

In the U.S.S.R. the problem of metallogenic provinces, epochs and maps were particularly discussed by the late Y. A. Bilibin (1901-52) and S. S. Smirnov (1895-1947), and at the present time this work occupies the forefront of geological research. Valuable contributions to the metallogeny of various ores were recently made by N. S. Shatsky, discussing the manganese ores (Bull. Acad. Sci. U.S.S.R., Ser. Geol., 4,$3 ; 1954$ ), and phosphorite deposits ("Conf. Sed. Rocks, Acad. Sci. U.S.S.R.", 2, 7 ; 1955). The metallogeny of Kazakhstan has been discussed by K. I. Satpaev (Bull. Acad. Sci. C.S.S.R., Ser. Geol., 6,$34 ; 1953$ ) and A. I. Semenov (Soviet Geology, 58, $110 ; 1957)$. The principles of regional metallogenic analysis have been discussed by V. I. Serpukhov (Soviet Geology, 43, 27 ; 1955). The principlos of metallogeny and the construction of metallogenic maps are discussed by E. T. Shatalov (Bull. Acad. Sci. U.S.S.R., Ser. Geol., 9, 37 ; 1958). An attempt at a general metallogenic survey of the territory of the Soviet Union and the construction of a metallogenic map of the U.S.S.R. was made by V.I. Smirnov (Bull. Acad. Sci. U.S.S.R., Ser. Geol., 4, 3; 1959 and Priroda, 4,$17 ; 1959)$. Recently, E. A. Radkevich (Bull. Acad. Sci. U.S.S.R., Ser. Geol., 5, 125 ; 1959) has published a report of the All-Union Metallogenic Conference held in Alma-Ata during December 1958, at which 800 delegates and visitors were present and a number of papers read and discussed. A valuable summary of the work done in the Soviet Union in this field combined with a manual for the preparation of metallogenic maps has been published in book form. It is edited by P. M. Tatarinov, V. G. Grushevoy and G. S. Labazin, and it is entitled "General Principles of a Regional Metallogenic Analysis and of the Methods of Compilation of Metallogenic Maps of Folded Regions", published by "Gosgeoltekhizdat", Moscow, 1957 (150 pages; price $7 \mathrm{r} .20 \mathrm{k}$.). This volume contains seven articles dealing with the general principles of a regional metallogenic analysis, sedimentary and igneous formations, mineral deposits complexes, metallogenic zones and methods of compilation of metallogenis: maps.
S. I. TOMKEIEFF 